\title{
PENGARUH LEVERAGE, UMUR PERUSAHAAN, PROFITABILITAS, FIRM SIZE, AUDIT FIRM SIZE TERHADAP VOLUNTARY DISCLOSURE
}

\author{
Fahma Dewi Firmaningtyas ${ }^{1)}$, Dinda Amelia Kusumastuti2 ${ }^{2}$ \\ Fakultas Ekonomi dan BisnisUniversitas PGRI Madiun \\ Email: fahma.elf@gmail.com ${ }^{1)}$
}

\begin{abstract}
Changes in economic conditions affect the business world, therefore companies must be more transparent in disclosing company information. The limitation of this research problem is the scope of information including Voluntary Disclosure while the information presented is leverage, age of the company, profitability, firm size and audit firm size. This study tries to analyze the determinants of the level of voluntary disclosure companies in BEI Manufacturing companies in 2015-2017. For this purpose the disclosure data is 65 data from BEI Manufacturing companies in 2015-2017, companies are selected and analyzed using multiple Linear regression. This study shows that the relationship of exogenous company level factors including profitability, firm size, audit firm size, company age and leverage on the voluntary disclosure index. The results of this study indicate that leverage, age of the company, Firm Size and Audit Firm size affect the area of voluntary disclosure or Voluntary Disclosure. While profitability has no effect on the area of Voluntary Disclosure disclosure.
\end{abstract}

Keywords: Voluntary Disclosure, profitability, company size, Audit Firm size, company age and leverage

\begin{abstract}
Abstrak
Perubahan kondisi lingkungan ekonomi mempengaruhi dunia usaha, karena itu perusahaan harus lebih transparan dalam mengungkapkan informasi perusahaannya. Batasan masalah penelitian ini ruang lingkup meliputi informasi Voluntary Disclosure sedangkan informasi yang disajikan yaitu leverage, umur perusahaan, profitabilitas, firm size dan audit firm size. Penelitian ini mencoba untuk menganalisis penentu tingkat perusahaan pengungkapan sukarela di perusahaan Manufaktur BEI Tahun 2015-2017,Untuk tujuan ini data pengungkapan sebanyak 65 data dari perusahaan Manufaktur BEI Tahun 2015-2017, perusahaan dipilih dan dianalisis menggunakan regresi Linier berganda. Studi ini menunjukkan bahwa hubungan faktor tingkat perusahaan eksogen termasuk profitabilitas, ukuran perusahaan, Audit Firm size, umur perusahaan dan leverage terhadap indeks pengungkapan sukarela (voluntary Disclosure). Hasil penelitian ini menunjukkan bahwa Leverage, umur perusahaan, Firm Size dan Audit Firm size berpengaruh pada luas pengungkapan sukarela atau Voluntary Disclosure.Sedangkan profitabilitas tidak berpengaruh terhadap luas pengungkapan Voluntary Disclosure.
\end{abstract}

Kata kunci: pengungkapan sukarela (Voluntary Disclosure), profitabilitas, ukuran perusahaan, Audit Firm size, umur perusahaan dan leverage

\section{PENDAHULUAN}

$\begin{array}{ccc}\begin{array}{c}\text { Dengan } \\ \text { lingkungan }\end{array} & \text { berubahnya } & \text { kondisi } \\ \text { ekonomi } & \text { banyak }\end{array}$ mempengaruhi dunia usaha. Perusahaan dihadapkan pada kondisi untuk dapat lebih transparan dalam mengungkapkan informasi perusahaannya, sehingga dapat membantu pengambil keputusan dalam mengantisipasi kondisi yang semakin berubah Laporan Tahunan yang disajikan setransparan mungkin yaitu apa adanya, tidak dibuat-buat, jujur, netral dan objektif.
Informasi yang diungkapkan dalam laporan tahunan ada dua, yaitu pengungkapan wajib (mandatory disclosure) dan pengungkapan sukarela (voluntary disclosure).Dengan pengungkapan ini mempelajari penyediaan informasi oleh perusahaan dalam laporan tahunan untuk memenuhi persyaratan peraturan dan pencatatan atau untuk mengurangi asimetri informasi antara manajer dan pemegang saham. Beberapa peneliti (Akhtaruddin, 2005; Glaum \& 
Street, 2003; Haniffa \& Cooke, 2002) berpendapat usia perusahaan menjadi penentu signifikan pengungkapan sukarela. Owusu-Ansah (1998) menjelaskan bahwa perusahaan yang baru didirikan mungkin menghadapi hal yang layak kesulitan jika mereka memberikan informasi sesuai dengan kemajuan dan peningkatan mereka.Akhirnya, leverage perusahaan dianggap sebagai faktor negatif yang mengurangi tingkat pengungkapan sukarela (Lihat misalnya; Hossain, et al. 1995; Jaggi \& Low, 2000; Khanna \& Srinivasan, 2004).Karena leverage tinggi bukanlah sesuatu yang dihargai oleh pemegang saham, maka perusahaan

\section{KAJIAN TEORI DAN PENGEMBANGAN HIPOTESA}

Teori Agency (Teori Keagenan)

Dengan pengungkapan kita akan mempelajari penyediaan informasi oleh perusahaan dalam laporan tahunan untuk memenuhi persyaratan peraturan dan pencatatan dan mengurangi asimetri informasi antara manajer dan pemegang saham.

\section{Voluntary Disclosure}

Disclosure(pengungkapan)

merupakansuatucarauntukmewujudkantra nsparansidalambidangbisnis,

selainitudisclosure ataslaporantahunan juga

dapatdigunakanuntukmeningkatkankeperc ayaan investor dan penggunalaporanlainnya. Variabelvariabel yang berpengaruhterhadappengungkapanyaitu $l$ everage, likuiditas, profitabilitas, sahampublic dan umurperusahaan (Simanjuntak dan Widiastuti,2004). Suripto (1998) variabel-variabel yang berpengaruhterhadappengungkapanyaitusi dengan rasio utang terhadap total aset yang tinggi menghindari mengungkapkan banyak informasi leverage kepada pemegang saham.

Penelitian ini menggunakan obyek perusahaaan Manufaktur BEI 2015-2017 dalampenelitianinihendak menganalisis faktor-faktor penentu tingkat perusahaan pengungkapan sukarela di perusahaan manufaktur dengan judul: "Pengaruh Umur Perusahaan,Leverage, Profitabilitas, Firm Size,Audit Firm Size terhadap Voluntary Disclosure (Studi pada Perusahaan Manufaktur BEI 2015-2017)"

ze, leverage, likuiditas, basis, waktuterdaftar, penerbitansekuritas dan kelompokindustri. Dari berbagaivariabel yang

dapatmempengaruhipengungkapanlapora nkeuangan, makadalampenelitianinidigunakan 3 (tiga) variableyaituleverage, firm size, dan profitability.

Ketigavariabletersebutdirasamempunyaik eterkaitan yangerat. Disclosure merupakanbagian integral daripelaporankeuangan.Ada duamacamjenispengungkapanberdasarkan sifatnyayaitupengungkapansukarela dan pengungkapanwajib

Menurut Meek, 1995bahwapengunkapan voluntary disclosure menggunakanpengungkapan 33 item pernyataan yang ada di annual report yang terdiridari 3 yaitukajianstartejik,keuangan dan non keuangan

Laverage

Leverage adalah hutang sumber dana yang digunakan perusahaan untuk membiayai asetnya diluar sumber dana 
modal atau ekuitas. Leverage perusahaan dianggap sebagai faktor negatif yang mengurangi tingkat pengungkapan sukarela (Lihat misalnya; Hossain, et al.1995; Jaggi\&Low,2000; Khanna \& Srinivasan,2004). Karena leverage tinggi bukanlah sesuatu yang dihargai oleh pemegang saham, maka perusahaan dengan rasio utang terhadap total aset yang tinggi menghindari mengungkapkan banyak informasi leverage kepada pemegang saham.

\section{Profitabilitas}

Tingkat Pengembalian Aset adalah rasio profitabilitas yang menunjukan persentase keuntungan (laba bersih) yang diperoleh perusahaan sehubungan dengan keseluruhan sumber daya atau rata-rata jumlah aset.Rasio ROA atau Return on Assets ini dapat membantu manajemen dan investor untuk melihat seberapa baik suatu perusahaan mampu mengkonversi investasinya pada aset menjadi keuntungan atau laba (profit).(Mirza,Muneeb,Asghar,2017) pengembalian aset ROA adalah penentu terpenting pengungkapan sukarela.

\section{Umur Perusahaan}

Umur perusahaan yaitu seberapa lama suatu perusahaan mampu untuk bertahan, bersaing, dan mengambil kesempatan bisnis yang ada dalam perekonomian (Syari'i,2013). Perusahaan yang sudah lama berdiri, kemungkinan sudah banyak pengalaman yang diperoleh.Semakin lama umur perusahaan, semakin banyak informasi yang telah diperoleh masyarakat tentang perusahaan tersebut. Dan hal ini akan menimbulkan kepercayaan konsumen terhadap perushaan-perusahaan tersebut.

\section{Firm Size}

Ukuran perusahaan merupakan skala yang dapat mengklasifikasikan bahwa perusahaan tersebut dikatakan besar atau kecil. Penelitian terdahulu yang dilakukan oleh Forte (2015), Monang dan Neng Lia (2015), dan Eko dan Ira (2014) menggunakan ukuran perusahaan sebagai variabel yang sering digunakan dalam meneliti luas pengungkapan sukarela dan hasilnya ukuran perusahaan berpengaruhpositif terhadap luas pengungkapan sukarela yang dilakukan oleh perusahaan,beberapa peneliti Jensen dan Meckling (1976) dan Stanga (1976) menyatakan bahwa biaya agensi dalam perusahaan ukuran besar lebih tinggi dibandingkan dengan yang lebih kecil oleh karena itu, perusahaan ukuran besar perlu mengungkapkan informasi yang relatif lebih banyak.

\section{Audit Firm size}

KAPBig 4dianggapcenderung memberikankualitasaudityang baik.Adaempatkelebihanskalaauditor menurutFirth\&LiauTan(1998) dalam Rossietadan Wibowo (2009),yaitu:

a. Besarnyajumlah danragam klienyangditanganiKAP; banyaknyaragam jasayangditawarkan;

b. Luasnya cakupan geografis, termasukadanya afiliasi international; dan

c. Banyaknya jumlah staf audit dalam suatu KAP.

Dalam

FebriantodanWidiastuty,DeAngelo(1981) berpendapat pula bahwa keduaindicatorkualitasaudithanyadimilikio lehkantorakuntanyangberukuranbesar.

\section{Kerangka Berpikir}


Selain ukuran perusahaan, kualitas audit merupakan penentu penting pengungkapan sukarela. Oleh karena itu, perusahaan audit salah satu dari empat perusahaan audit besar dapat mengungkapkan lebih banyak informasi secara sukarela. Beberapa peneliti (Lihat contoh; Akhtaruddin,2005; Glaum \& Street, 2003; Haniffa\& Cooke,2002) berpendapat bahwa umur perusahaan menjadi penentu signifikan pengungkapan sukarela.

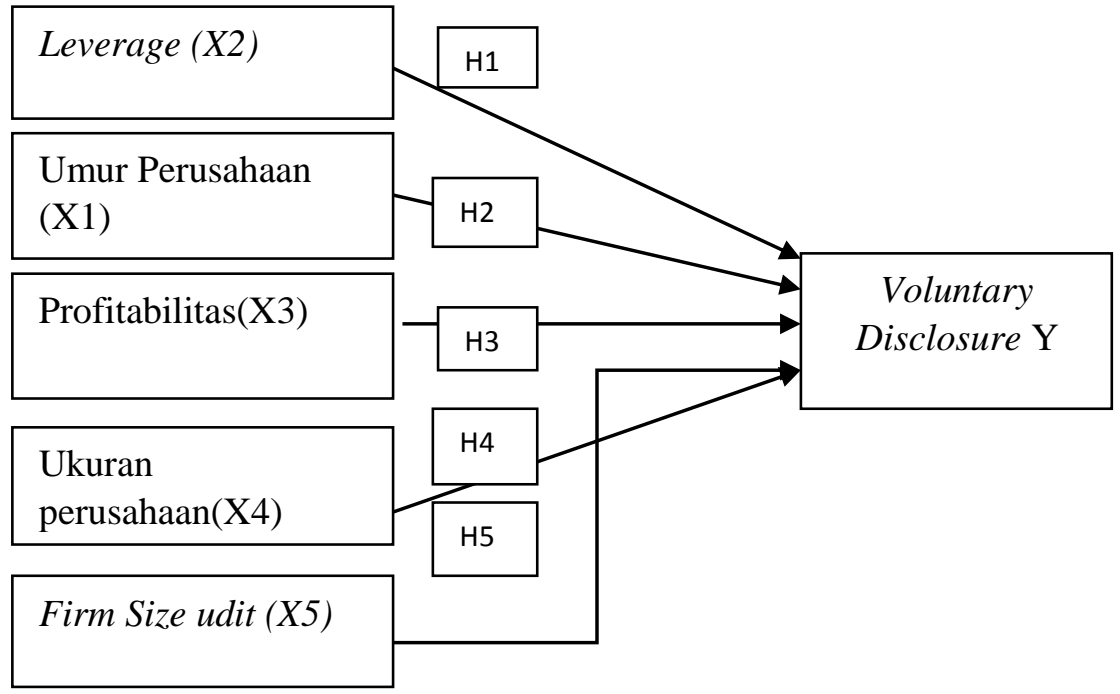

\section{Pengembangan Hipotesa}

Pengaruh Umur Perusahaan berpengaruh terhadap Voluntary Disclosure

Umur perusahaan yaitu seberapa lama suatu perusahaan mampu untuk bertahan, bersaing, dan mengambil kesempatan bisnis yang ada dalam perekonomian (Syari'i,2013). Beberapa penelitian yang membuktikan umur perusahaan berpengaruh terhadap pengungkapan sukarela usia perusahaan menjadi penentu signifikan pengungkapan sukarela (Akhtaruddin,2005; Glaum \& Street,2003; Haniffa \& Cooke,2002). Berdasarkan penelitian terdahulu maka dapat disimpulkan bahwa :

H1: Umur perusahan berpengaruh terhadap Voluntary Disclosure

Pengaruh Leverage terhadap Voluntary Disclosure

Leverage merupakan perbandingan antara hutang dengan aktiva yang menunjukkan kemampuan perusahaan dalam memenuhi kewajibannya (Suta, 2012). Leverage dapat digunakan sebagai suatu ukuran untuk menilai risiko struktur pendanaan perusahaan (Wardani,2012). Karena leverage tinggi bukanlah sesuatu yang dihargai oleh pemegang saham. Berdasarkan penelitian terdahulu maka dapat disimpulkan bahwa :

$\mathrm{H} 2$ : Leverage tidakberpengaruh terhadap Voluntary Disclosure

Pengaruh Profitabilitas terhadap Voluntary Disclosure

Rasio ROA atau Return on Assets ini dapat membantu manajemen dan investor untuk melihat seberapa baik suatu perusahaan mampu mengkonversi investasinya pada aset menjadi keuntungan atau laba (profit). Ada dua cara umum dalam menghitung ROA yaitu dengan menghitung total aset pada tanggal tertentu atau dengan menghitung rata-rata total aset 


\section{(average}

total assets). (Mirza,Muneeb,Asghar,2017)

Berdasarkan penelitian terdahulu maka dapat disimpulkan bahwa :

H3: Profitabilitas berpengaruh terhadap Voluntary Disclosure

Pengaruh Ukuran Perusahaan terhadap Voluntary Disclosure

Teori sinyal menjelaskan bahwa dimana semakin besar perusahaan maka semakin banyak informasi perusahaan yang diberikan oleh manajemen perusahaan kepada investor atau kreditor. Penelitian terdahulu yang dilakukan oleh Forte (2015), Monang dan Neng Lia (2015), dan Eko dan Ira (2014) menggunakan ukuran perusahaan sebagai variabel yang sering digunakan dalam meneliti luas pengungkapan sukarela dan hasilnya ukuran perusahaan berpengaruh positif terhadap luas pengungkapan sukarela. Berdasarkan penelitian terdahulu maka dapat disimpulkan bahwa :

H4: Ukuran Perusahaan berpengaruh terhadap Voluntary Disclosure

Pengaruh Firm Size Audit terhadap Voluntary Disclosure

Firth (1979) berpendapat bahwa Firm size audit yang lebih besar dapat mempengaruhi perusahaan untuk memberikan informasi terkait inklusif, tentang kebijakan perusahaan untuk menjaga reputasi mereka. Dopuch dan Simunic (1980) dalam Lawrenceetal. (2011) menyatakan pula bahwa KAP yang lebih besar dapat memberikan kualitas yang lebih tinggi pula karena memiliki reputasi yang tinggi. Berdasarkan penelitian terdahulu maka dapat disimpulkan bahwa :

H5: Firm Size Audit berpengaruh terhadap Voluntary Disclosure

\section{METODE PENELITIAN}

Jenis data yang digunakan dalam penelitian ini adalah data sekunder yang sumber datanya diperoleh dari www,idx.co.id,saham OK dan yahoo Finance untuk periode pengamatan Tahun 2015-2017 secara tahunan dan Laporan Tahunan Perusahaan. Populasi dalam penelitian ini adalah seluruh perusahaan Manufaktur yang sahamnya terdaftar di BEI sejak 2015-2017 yang berjumlah 156 perusahaan yang seperti ditunjukkan pada Tabel 1. Untuk menentukan sampel digunakan teknik sampel purposive sampling dengan kriteria:

1. Perusahaan non keuangan yang listed di BEI yang selalu menyajikan laporan keuangan selama periode pengamatan (2015-2017)

2. Perusahaan yang listed di BEI menggunakan satuan mata uang rupiah

\section{Tabel 1. Purposive Sampling}

\begin{tabular}{llc}
\hline No & Kriteria & Keterangan \\
\hline 1 & $\begin{array}{l}\text { Perusahaan Manufaktur yang listed di BEI yang periode } \\
\text { pengamatan (2015-2017); }\end{array}$ & 156 \\
2 & $\begin{array}{l}\text { Perusahaan Manufaktur yang listed di BEIselama periode } \\
\text { pengamatan (2015-2017) yang tidak menyajikan laporan } \\
\text { keuangan secara lengkap }\end{array}$ & \\
3 & $\begin{array}{l}\text { Perusahaan Manufaktur yang listed di BEIselama periode } \\
\text { pengamatan (2015-2017) yang menggunakan mata uang } \\
\text { selain rupiah }\end{array}$ & \\
Total & & \\
& & 23 \\
\hline
\end{tabular}


Jadi Perusahaan yang menjadi sampel dari penelitian ini adalah 23 Perusahaan Manufaktur di BEI Tahun 2015-2017, jumlah data $23 \times 3=69$, data outlier 3 sehingga jumlah data pengamatan menjadi 66 data

\section{Metode Pengumpulan Data}

Sesuai dengan jenis data yang diperlukan yaitu data sekunder maka teknik pengumpulan data untuk keperluan penelitian ini digunakan data sekunder di www.idx.co.idsaham $O K$ dan yahoo Finance perusahaan Manufaktur BEI Tahun pengamatan 2015-2017 dan Laporan Pengungkapan sukarela tiap perusahaan.

Definisi Operasional variable dan Pengukurannya

Secara garis besar definisi operasional variabel digambarkan pada Tabel 3.3 berikut ini:

Tabel 2. Definisi Operasional Variabel Penelitian

\begin{tabular}{|c|c|c|c|c|}
\hline No & Variabel & Definisi & Skala & Pengukuran \\
\hline 1 & $\begin{array}{l}\text { Umur } \\
\text { Perusahaan }\end{array}$ & $\begin{array}{l}\text { Menjelaskan bahwa umur } \\
\text { perusahaan Tahun penelitian } \\
\text { dikurangi tahun pendirian } \\
\text { (IPO), Owusu-Ansah (1998) }\end{array}$ & nominal & $\begin{array}{l}\text { Tahun penelitian } \\
\text { tahun pendirian (IPO) }\end{array}$ \\
\hline 2 & Leverage & $\begin{array}{l}\text { Leverage diukur melalui } \\
\text { hutang terhadap total nilai asset } \\
\text { (Mirza, Muneeb, Asghar,2017) }\end{array}$ & Rasio & $\frac{\text { Hutang. }}{\text { Total aset }}$ \\
\hline 3 & Profitabilitas & $\begin{array}{l}\text { Rasio pengembalian aset yang } \\
\text { diukur dengan laba bersih } \\
\text { perusahaan terhadap total aset } \\
\text { (Mirza, Muneeb, Asghar, } \\
\text { 2017) }\end{array}$ & Rasio & $\frac{\text { Laba bersih }}{\text { Total Asset }}$ \\
\hline 4 & $\begin{array}{l}\text { Ukuran } \\
\text { Perusahaan }\end{array}$ & $\begin{array}{l}\text { Ukuran perusahaan diproxykan } \\
\text { dengan Ln total aset, } \\
\text { Monang dan Neng Lia (2015) }\end{array}$ & Rasio & Ln ( Total Aset ) \\
\hline 5 & $\begin{array}{l}\text { Firm } \\
\text { Audit }\end{array}$ & $\begin{array}{l}\text { ukuran perusahaan audit yang } \\
\text { merupakan variabel dummy } \\
\text { dengan nilai } 1 \text { jika perusahaan } \\
\text { audit berada di antara lima } \\
\text { besar dan } 0 \text { sebaliknya } \\
\text { (Mirza, Muneeb, Asghar,2017) }\end{array}$ & nominal & $\begin{array}{l}1=\text { Perusahaan audit } \\
\text { masuk dalam big } 4 \\
0=\text { Perusahaan audit } \\
\text { tidak masuk dalam big } 4\end{array}$ \\
\hline
\end{tabular}




\begin{tabular}{|c|c|c|}
\hline $\begin{array}{l}\text { Voluntary } \\
\text { Disclosure }\end{array}$ & $\begin{array}{l}\text { indeks } 4 r \text { pengungkapan } \\
\text { perusahaan i dan RSCR adalah } \\
\text { skor mentah spesifik } \\
\text { perusahaan di mana setiap } \\
\text { pengungkapan adalah elemen } \\
\text { dari sistem biner yang nilainya } \\
1 \text { jika perusahaan telah } \\
\text { mengungkapkan informasi } \\
\text { tertentu dan 0 sebaliknya. } \\
\text { Demikian pula, MSCR } \\
\text { mewakili skor maksimum } 33 \\
\text { skor atau jumlah maksimum } \\
\text { pengungkapan k oleh } \\
\text { perusahaan mana pun dengan } \\
\text { mengacu pada } 33 \text { elemen } \\
\text { voluntary disclosure pada } \\
\text { annual report masing masing } \\
\text { perusaahaan (Meek,1995 dan } \\
\text { Mirza, Muneeb, Asghar, 2017) }\end{array}$ & $\begin{array}{l}\text { DCORE = } \\
\frac{\sum \mathrm{RSCR}}{\sum \mathrm{MSCR}} \\
\mathrm{I}=(1,2 \ldots \mathrm{n}):\end{array}$ \\
\hline
\end{tabular}

Sumber: data diolah 2019

\section{Teknik Analisa Data}

Penelitian ini dengan menggunakan pendekatan kuantitatif. Secara umum, pendekatan kuantitatif lebih fokus pada tujuan untuk generalisasi, dengan melakukan pengujian statistik dan steril dari pengaruh subjektif peneliti (Ghozali, 2005). Alat analisis yang digunakan dalam penelitian ini adalah analisis regresi linier berganda dengan program SPSS. Analisis regresi berganda adalah analisis mengenai beberapa variabel independen dengan satu variabel dependen.

Penelitian ini menganalisis pengaruh Umur perusahaan, Leverage, Profitabilitas, Ukuran Perusahaan, Firm Size Audit .Langkah yang dilakukan dalam analisis tersebut masing-masing akan dijelaskan di bawah ini:

\section{HASIL DAN PEMBAHASAN}

Penelitianinimenggunakan data sekunder yaitu www,idx.co.id untuk periode pengamatan Tahun 2015-2017 secara tahunan dan Laporan Tahunan Perusahaan Manufaktur BEI. Serta mencarihargapenutupansaham di saham OK dan yahoo Finance.Jumlahsampel perusahaan yang digunakansebanyak23 perusahaan Manufaktur yang memiliki data lengkap selama tigatahun.Sedangkan3 data Outlier sehinggasampel data yang dianalisis sebanyak 66 data pengamatan.

\section{DeskripsiStatistikVariabelPenelitian}

$$
\text { Pada tabel } \quad 4.1
$$

disajikandeskripsiuntukvariabledependen yang digunakanuntukmengujihipotesispenelitian , yaituVoluntary Disclosure.

\section{Tabel 3. Hasil Uji Data Deskriptif}

\begin{tabular}{llllll} 
& $\mathrm{N}$ & Minimum & Maximum & Mean & Std. Deviation \\
\hline AGE & 66 & .000 & 1.544 & 1.14533 & .362277 \\
\hline
\end{tabular}




\begin{tabular}{llllll}
\hline LEV & 66 & .034 & .729 & .38395 & .189302 \\
ROA & 66 & -.920 & .505 & .06064 & .201518 \\
SIZE & 66 & 25.619 & 30.847 & 28.28226 & 1.377210 \\
AUDITFIRM & 66 & 0 & 1 & .38 & .489 \\
VOLUNTARY & 66 & .424 & .545 & .49355 & .038751 \\
Valid N (listwise) & 66 & & & &
\end{tabular}

Sumber: Data sekunderdiolah (2019)

Umur Perusahaan digunakanmenjelaskan bahwa umur perusahaan Tahun penelitian dikurangi tahun pendirian (IPO), Owusu-Ansah (1998)Umur Perusahaan mempunyai data maksimumsebesar1,544serta minimum 0,000,sedangkan

Leveragemaksimumsebesar0,729serta minimum sebesar0,034,Profitabilitas (ROA)data maksimumsebesar0,505serta minimum -0,920,UkuranPerusaahaan (Size) data maksimumsebesar30,847serta minimum 25,619,Firm Audit size data maksimumsebesar 1serta minimum 0,Voluntary Disclosuredata maksimumsebesar0,545serta minimum 0,424

\section{Pengujian Hipotesis \\ Hasil Uji Normalitas}

Tabel 4 menunjukkan hasil uji kolmogorov-smirnov. Berdasarkan tabel 4.2 dapat disimpulkan bahwa data yang digunakan dalam penelitian ini memiliki distribusi normal. Hal initerlihat pada nilai $Z_{\text {kolmogorov-smirnov residual varaibel }}$ independen Leverage, Umur Perusahaan, Profitabilitas ,Firm Size dan Audit Firm Sizedengan residual hasil regresi dengan variabel dependen terhadap Voluntary Disclosure memiliki nilai 0,081 lebih besar dari 0,05 (Ghozali,2009) maka data dapat dikatakan berdistribusi normal.

Tabel4Hasil Uji NormalDengan Uji Kolmogorov-Smirnov

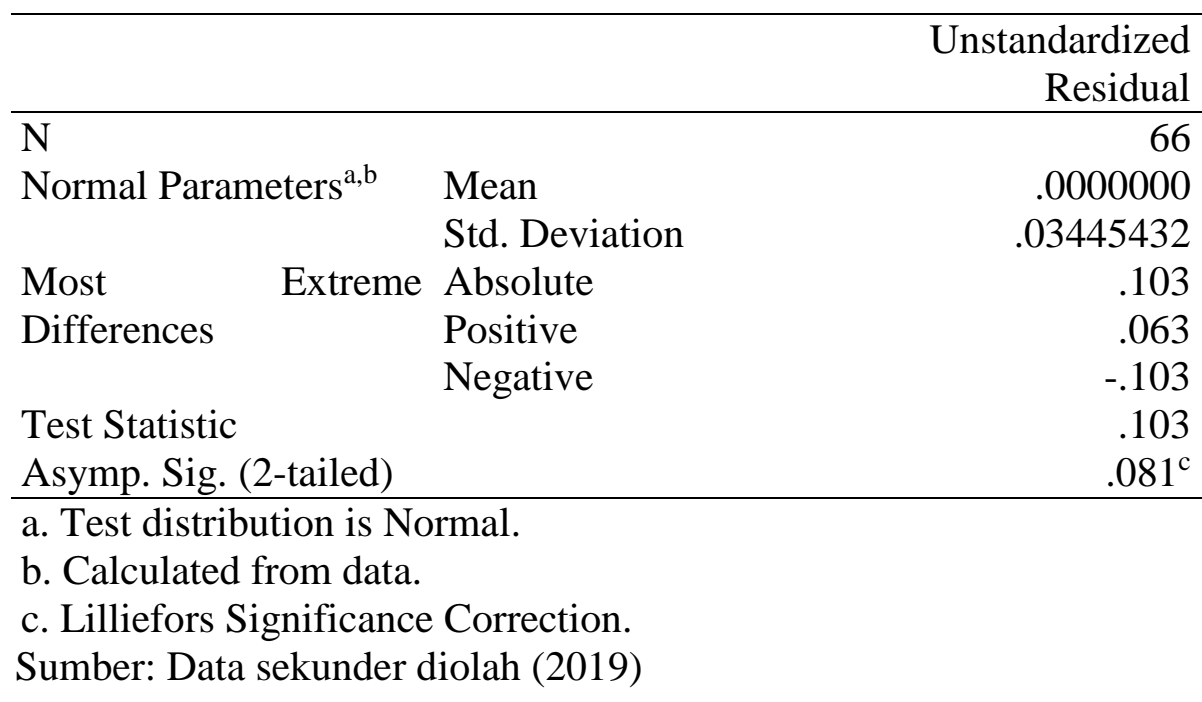

\section{Hasil Uji Autokorelasi}

Bila angka Durbin-Watson diantara -2 sampai +2 , berarti tidak ada autokorelasi. 
(Ghozali, 2006:100). Dari tabel DurbinWatsonterlihatangka D-W sebesar0,593.Karena angkaDurbin-Watson diantara -2 sampai +2 , berarti tidak ada autokorelasi.Makahaliniberarti pada model regresitidakadaautokorelasipositifataunegat if, ataudapatdisimpulkantidakterdapatautokor elasi.

Tabel 5.Hasil Uji Autokorelasi

\begin{tabular}{lccccc}
\hline Model & $\mathrm{R}$ & $\begin{array}{c}\mathrm{R} \\
\text { Square }\end{array}$ & $\begin{array}{c}\text { Adjusted R } \\
\text { Square }\end{array}$ & $\begin{array}{c}\text { Std. Error of } \\
\text { the Estimate }\end{array}$ & $\begin{array}{c}\text { Durbin- } \\
\text { Watson }\end{array}$ \\
\hline 1 & $.458^{\mathrm{a}}$ & .209 & .144 & .035861 & .593
\end{tabular}

Sumber:outputSPSS (data sekunderdiolah, 2019)

\section{Hasil Multikolinearitas}

Uji

multikolinearitasbertujuanuntukmengujiap akah di dalam model regresiditemukanadanyakorelasiantarvaria blebebas.Multikolinearitas terjadi jika nilai VIF (Varian inflation factor) $<10$; dan jika tolerance $>0,1$. Dari hasil analisis program SPSS, pada bagian koefisien untuk keempat variabel independen terlihat bahwa nilai tolerance diatas 0,1 dan nilai VIF jauh dibawah angka 10. Hasil uji multikolinearitas ditunjukkan oleh tabel berikut ini:

Tabel 6. HasilUjiMultikolinearitasdenganNilaiTolerance dan VIF

\begin{tabular}{|c|c|c|c|c|c|c|c|c|c|c|c|}
\hline Model & & \multicolumn{2}{|c|}{$\begin{array}{l}\text { Unstd. } \\
\text { Coefficients }\end{array}$} & $\begin{array}{l}\text { Std.Coe } \\
\text { fficients } \\
\text { Beta }\end{array}$ & $\mathrm{T}$ & Sig. & \multicolumn{3}{|c|}{ Correlations } & \multicolumn{2}{|c|}{ Coll. Stat } \\
\hline 1 & (Constant) & .238 & .107 & & 2.225 & .030 & & & & & \\
\hline & AGE & .036 & .013 & .333 & 2.665 & .010 & .176 & .325 & .306 & .842 & 1.188 \\
\hline & LEV & -.066 & .026 & -.321 & -2.543 & .014 & -.179 & -.312 & -.292 & .826 & 1.210 \\
\hline & ROA & -.015 & .023 & -.077 & -.657 & .514 & -.039 & -.085 & -.075 & .951 & 1.052 \\
\hline & SIZE & .009 & .004 & .317 & 2.292 & .025 & .069 & .284 & .263 & .687 & 1.455 \\
\hline & $\begin{array}{l}\text { AUDITFIR } \\
\mathrm{M}\end{array}$ & -.031 & .011 & -.389 & -2.843 & .006 & -.176 & -.345 & -.326 & .704 & 1.420 \\
\hline
\end{tabular}

a. Dependent Variable: VOLUNTARY

Sumber:outputSPSS (data sekunderdiolah, 2019)

Dari tabel 6 dapat diketahui bahwa nilai tolerance untuk setiap variabel independen diatas 0,1 dan VIF kurang dari 10, sehingga dapat disimpulkan bahwa model regresi dalam penelitian ini bebas dari masalah multikolinearitas.

\section{Hasil Uji Heteroskedastisitas Uji}

Heteroskedastisitasbertujuanmengujiapaka hdalam

model regresiterjadiketidaksamaanvariance dari residual satupengamatankepengamatan yang lain. Jikaadapola yang tertentu, makatelahterjadiheteroskedastisitas.Hetero skedastisitas dalam penelitian ini diuji dengan meregresikan variabel independen Leverage, UmurPerusahaan,Profitabilitas, $F i$ rm Size danAudit Firm Sizedengan residual hasil regresi dengan variabel dependen terhadapVoluntary Disclosure.Kreteria ada tidaknya gelaja Heteroskedastisitas adalah 
apabila signifikansinya diatas 0,05 berarti model regresi menunjukkan tidak adanya permasalahan heteroskedastisitas (Ghozali, 2009).

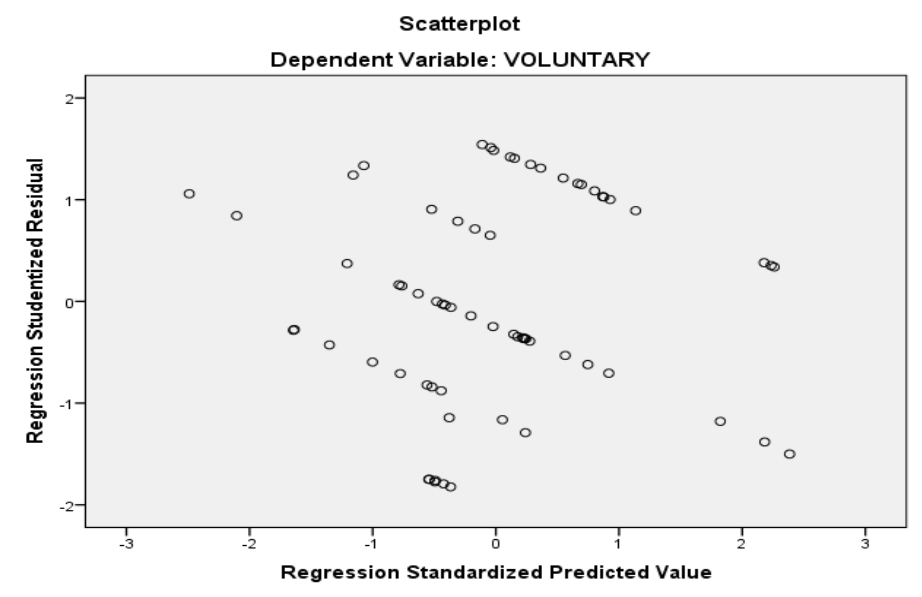

Gambar 1Hasil Heteroskedastisitas

Dari gambar 1 dapat dilihat bahwa data menyebarheterogen Dari hasil tersebut dapat disimpulkan bahwa variabel variabel independen dalam penelitian ini bebas heteroskedastisitas.

\section{UjiHipotesis}

\section{Persamaan regresi Linear Berganda}

Untuk mengetahui pengaruh variabel bebas dalam penelitian ini, maka di susun persamaan regresi berganda. Regresi berganda dalam penelitian ini digunakan untuk mengetahui pengaruh variabel-variabel bebas Leverage (LEV),Umur (AGE),Profitabilitas(ROA),Firm

Size(SIZE) dan Audit Firm Size (FIRM_SIZE)terhadapVoluntary

Disclosure. Analisis regresi tersebut menghasilkan koefisien-koefisien regresi yang menunjukkan arah hubungan sebab akibat antara variabel bebas dan variable terikat.Berdasarkan perhitungan komputer program statistik SPSS diperoleh persamaan regresi linear berganda sebagai berikut:

$$
\mathrm{Y}=\quad 0,238+0,036 \mathrm{X}_{1}-0,066 \mathrm{X}_{2}-0,015 \mathrm{X}_{3}+0,009 \mathrm{X}_{4}-0,031 \mathrm{X} 5+\mathrm{e}
$$

Keterangan:

$$
\mathrm{E}=\text { standart error }
$$

$\begin{array}{ll}\mathrm{Y} & =\text { disclosure } \\ & =\text { Uoluntary } \\ \mathrm{X}_{1} & =\text { Umur perusahaan } \\ \mathrm{X}_{2} & =\text { Leverage } \\ \mathrm{X}_{3} & =\text { ROA Ukuran } \\ \mathrm{X}_{4} & =\text { Perusahaan } \\ & \text { X5 }\end{array}$

\section{Koefisien Determinasi}

Koefisien determinasi adalah nilai yang menunjukkan proporsi pengaruh variabel independen yang dapat menjelaskan variabel dependen. Koefisien determinasi dinyatakan dalam prosentase (Ghozali, 2009). Hasil pengujian menggunakan SPSS didapatkan nilai koefisien deterninasi seperti pada tabel berikut ini:

Tabel 7. Koefisien Deterninasi 


\begin{tabular}{llllll} 
& & $\mathrm{R}$ & Adjusted R & Std. Error of Durbin- \\
Model & $\mathrm{R}$ & Square & Square & $\begin{array}{l}\text { Dstimate } \\
\text { Watson }\end{array}$ \\
\hline 1 & $.458^{\mathrm{a}}$ & .209 & .144 & .035861 & .593 \\
\hline
\end{tabular}

Sumber:outputSPSS (data sekunderdiolah, 2019)

Dari tabel diatas dapat diketahui nilai Adjusted R Square sebesar 0,144 nilai ini menunjukkan bahwa Leverage (LEV),Umur Perusahaan (AGE),Profitabilitas(ROA),Firm

Size(SIZE),Audit Firm Size
(FIRM_SIZE)terhadapVoluntary

Disclosureperusahaan Manufaktur yang go public di BEI tahun 2015 - 2017 sebesar $14,4,0 \%$, sedangkan sisanya sebesar $85,6 \%$ dijelaskan oleh variabel lain yang tidak dimodelkan dalam penelitian ini.

\section{Uji t (Pengaruh Parsial)}

Uji t digunakan untuk mengetahui pengaruh masing-masing variable independen, yaitu Leverage (LEV),Umur Perusahaan (AGE),Profitabilitas(ROA),Firm Size(SIZE) dan Audit Firm Size (FIRM_SIZE)terhadapVoluntary

Disclosureperusahaan Manufaktur yang go public di BEI tahun 2015 hingga 2017. Pengambilan keputusan didasarkan pada probabilitas signifikansi 0,05 (5\%).

Tabel8.Hasil Uji Parsial

\begin{tabular}{|c|c|c|c|c|c|c|}
\hline \multirow[b]{2}{*}{ Model } & & \multicolumn{2}{|c|}{$\begin{array}{l}\text { Unstandardized } \\
\text { Coefficients }\end{array}$} & \multicolumn{2}{|c|}{$\begin{array}{l}\text { Standardized } \\
\text { Coefficients }\end{array}$} & \multirow[b]{2}{*}{ Sig. } \\
\hline & & B & Std. Error & Beta & $\mathrm{T}$ & \\
\hline \multirow[t]{6}{*}{1} & (Constant) & .238 & .107 & & 2.225 & .030 \\
\hline & AGE & .036 & .013 & .333 & 2.665 & .010 \\
\hline & LEV & -.066 & .026 & -.321 & -2.543 & .014 \\
\hline & ROA & -.015 & .023 & -.077 & -.657 & .514 \\
\hline & SIZE & .009 & .004 & .317 & 2.292 & .025 \\
\hline & AUDITFIRM & -.031 & .011 & -.389 & -2.843 & .006 \\
\hline
\end{tabular}

$\mathrm{Uji}$

Signifikansimasingmasingvariablediuraikansebagaiberikut:

\section{Umur Perusahaan(AGE)}

Berdasarkan hasil perhitungan dengan menggunakan program SPSS seperti terlihat pada tabel 4.7, diperoleh koefisien regresi variabel Umur Perusahaan (AGE) sebesar 0,036 dengan nilai thitung 2,665 dan signifikansi sebesar 0,010 . Ketentuan pengambilan keputusan hipotesis diterima atau ditolak didasarkan pada besarnya nilai signifikansi. Jika signifikansi lebih kecil atau sama dengan 0,05 maka hipotesis diterima dan sebaliknya. Hasil penelitian diperoleh nilai signifikansi sebesar 0,010. $(<0.05)$. Berdasar hasil uji diatas dapat disimpulkan bahwa hipotesis pertama $\left(\mathrm{H}_{1}\right)$ yaitu $\mathrm{H} 1$ : Umur perusahaan berpengaruh terhadap Voluntary Disclosure pada perusahaan Manufaktur di BEI Tahun 2015-2017, adalah didukung.

\section{Leverage (LEV)}


Berdasarkanhasilperhitungandenga nmenggunakan program SPSS sepertiterlihat pada tabel 4.7, diperolehkoefisienregresivariableLeverage sebesar-0,066dengannilai $\mathrm{t}$ hitung-2.543 dan signifikansisebesar $\quad 0,14$. Jikasignifikansilebihkecilatausamadengan 0,05 makahipotesisditerima dan sebaliknya. Hasil penelitiandiperolehnilaisignifikansisebesar 0,14(<0.05) , Berdasar hasil uji diatas dapat disimpulkanbahwahipotesis kedua $\left(\mathrm{H}_{2}\right) \quad$ yaitu Leverage tidakberpengaruhterhadapVoluntary

Disclosurepada perusahaan Manufaktur di BEI Tahun 2015 - 2017, adalah didukung.

Profitabilitas (ROA)

Berdasarkan hasil perhitungan dengan menggunakan program SPSS seperti terlihat pada tabel 4.7 , diperoleh koefisien regresivariabel $R O A$ sebesar- 0,15 dengan nilai $\mathrm{t}$ hitung $-0,657$ dan signifikansi sebesar 0,514 Jika signifikansi lebih kecil atau sama dengan 0,05 maka hipotesis diterima dan sebaliknya. Hasil penelitian diperoleh nilai signifikansi sebesar 0,514 (>0.05). Berdasar hasil uji diatas dapat disimpulkan bahwa hipotesis ketiga yaitu H3: Profitabilitas berpengaruh terhadap Voluntary Disclosure pada perusahaan Manufaktur di BEI Tahun 2015-2017, adalah tidak didukung.

Ukuran Perusahaan (SIZE)

Berdasarkanhasilperhitungandengan menggunakan program SPSSsepertiterlihat pada tabel 4.7, diperolehkoefisienregresivariableUkuran Perusahaan (SIZE) sebesar0,009dengannilai t hitung2.292 dan signifikansisebesar 0,025Jikasignifikansilebihkecilatausamade ngan 0,05 makahipotesisditerima dan sebaliknya. Hasil penelitiandiperolehnilaisignifikansisebesar 0,025 (<0.05) Berdasar hasil uji diatas dapat disimpulkanbahwahipotesis keempatya itu H4: Ukuran Perusahaan berpengaruhpositifterhadapVoluntary

Disclosurepada perusahaan Manufaktur di BEI Tahun 2015 - 2017, adalahdidukung.

\section{Audit Firm Size (Firm Audit)}

Berdasarkan hasil perhitungan dengan menggunakan program SPSS seperti terlihat pada tabel 4.7, diperoleh koefisien regresi variabel Audit Firm Size (Firm Size) sebesar -0.031 dengan nilai $\mathrm{t}$ hitung $-2,843$ dan signifikansi sebesar 0,006. Jika signifikansi lebih kecil atau sama dengan 0,05 maka hipotesis diterima dan sebaliknya. Hasil penelitian diperoleh nilai signifikansi sebesar 0,006 $(<0.05)$ Berdasar hasil uji diatas dapat disimpulkan bahwa hipotesis kelima yaitu H5: Firm Size Audit berpengaruh terhadap Voluntary Disclosure pada perusahaan Manufaktur di BEI Tahun 2015-2017, adalah didukung.

\section{HASIL DAN PEMBAHASAN}

PengaruhUmur Perusahaan terhadapVoluntary Disclosure

Hasil uji hipotesis pertama yaitu Umur Perusahaan berpengaruh terhadap Voluntary Disclosure pada perusahaan Manufaktur di BEI Tahun 2015-2017, menunjukkan Umur Perusahaan terhadap Corporate Financial Performance adalah berpengaruh.

\section{Pengaruh Leverage terhadapVoluntary Disclosure}

Hasil uji hipotesis kedua yaitu Leverageberpengaruh terhadap Voluntary DisclosureHasil penelitian ini mendukung 
Leveragedapatdigunakansebagaisuatuukur anuntukmenilairisikostrukturpendanaanper usahaan (Wardani, 2012).

\section{PengaruhProfitabilitasterhadapVoluntar} y Disclosure

Hasil uji hipotesis ketiga yaitu Profitabilitas tidak berpengaruh terhadap Voluntary Disclosure Hasil penelitian ini mendukung Rasio ROA atau Return on Assets ini dapat membantu manajemen dan investor untuk melihat seberapa baik suatu perusahaan mampu mengkonversi investasinya pada aset menjadi keuntungan atau laba (profit). Ada dua cara umum dalam menghitung ROA yaitu dengan menghitung total aset pada tanggal tertentu atau dengan menghitung rata-rata total aset (average total assets). (Mirza, Muneeb, Asghar, 2017)

\section{Pengaruh Ukuran Perusahaan terhadapVoluntary Disclosure}

Hasil uji hipotesis keempat yaitu Ukuran Perusahaan berpengaruh terhadap Voluntary Disclosure Hasil penelitian ini mendukung Forte (2015), Monang dan Neng 2015), dan Eko dan Ira (2014) menggunakan ukuran perusahaan sebagai variabel yang sering digunakan dalam meneliti luas pengungkapan sukarela dan hasilnya ukuran perusahaan berpengaruh positif terhadap luas pengungkapan sukarela yang dilakukan oleh perusahaan.

\section{Pengaruh Firm Size Audit terhadap Voluntary Disclosure}

Hasil uji hipotesis kelima yaitu Firm Size Audit berpengaruh terhadap Voluntary Disclosure Hasil penelitian ini mendukung DeAngelo (1981) berpendapat pula bahwa kedua indikator kualitas audit hanya dimiliki oleh kantor akuntan yang berukuran besar. Pendapat ini didukung oleh Lee (1993) dalam Febrianto dan Widiastuty.

\section{KESIMPULAN DAN SARAN}

Tujuan penelitian ini adalah untuk mengetahui "Pengaruh Umur Perusahaan, Leverage, Profitabilitas, Firm Size dan Audit Firm Size terhadap Voluntary Disclosure (Studi pada Perusahaan Manufaktur BEI 2015-2017)".Dari hasilpengujian yang dilakukanterhadap23perusahaanselamatiga tahun dengan 66 data observasi diperoleh kesimpulan sebagai berikut:

1. Umur Perusahaan (AGE) berpengaruh terhadapVoluntary

Disclosureperusahaan manufakur di BEI Tahun 2015-2017

2. Leverage (LEV)berpengaruh terhadapVoluntary

Disclosureperusahaan manufakur di BEI Tahun 2015-2017

3. Profitabilitas (ROA)tidakberpengaruh terhadap Voluntary Disclosure perusahaan manufakur di BEI Tahun 2015-2017

4. Ukuran Perusahaan (SIZE) berpengaruh terhadap Voluntary Disclosure perusahaan manufakur di BEI Tahun 2015-2017

5. Audit Firm Sizeberpengaruh terhadap Voluntary Disclosure perusahaan manufakur di BEI Tahun 2015-2017

Berdasarkan hasil - hasil penelitian di atas, beberapa saran berkaiatan hasil yang diperoleh antara lain:

1. Penelitian ini tidak menemukan bukti bahwa ROA membatasi perusahaan dari pengungkapan informasi secara sukarela dalam laporan tahunan. Ada beberapa faktor yang mengurangi generalisasi hasil penelitian ini. Terutama, jumlah variabel yang 
terbatas dipertimbangkan dalam model.

2. Kemungkinan ada faktor-faktor lain yang merupakan penentu pengungkapan yang lebih penting. Kedua, ketersediaan laporan yang dipublikasikan dari semua perusahaan adalah kendala dari penelitian ini. Selanjutnya, penelitian saat ini dilakukan di sektor manufaktur BEI. Peneliti masa depan juga dapat mempelajari pengungkapan dan dinamika di sektor keuangan

\section{DAFTAR PUSTAKA}

Adelopo, I. (2011). Voluntary disclosure practices amongst listed companies in Nigeria. Advances in Accounting, 27(2), 338-345.

Ahmed, K., \& Courtis, J. K. (1999). Associations between corporate characteristics and disclosure levels in annual reports: a meta-analysis. The British Accounting Review, 31(1), 35-61.

Akhtaruddin, M. (2005). Corporate mandatory disclosure practices in Bangladesh. The International Journal of Accounting, 40(4), 399422.

Allegrini, M., \& Greco, G. (2013). Corporate boards, audit committees and voluntary disclosure: Evidence from Italian listed companies. Journal of Management \& Governance, 17(1), 187-216.

Blacconiere, W. G., Frederickson, J. R., Johnson, M. F., \& Lewis, M. F. (2011). Are voluntary disclosures that disavow the reliability of mandated fair value information informative or opportunistic?. Journal of Accounting and Economics, 52(2), 235-251.

Choi, F. D. (1973). Financial disclosure and entry to the European capital market. Journal of Accounting Research, 159-175.

Chow, C. W., \& Wong-Boren, A. (1987).Voluntary financial disclosure by Mexican corporations.Accounting review, 533-541.

Depoers, F. (2000). A cost benefit study of voluntary disclosure: Some empirical evidence from French listed companies. European Accounting Review, 9(2), 245-263.

Easterbrook, F. H. (1984). Two agencycost explanations of dividends. The American Economic Review, 74(4), 650-659.

Ferguson, M. J., Lam, K. C., \& Lee, G. M. (2002). Voluntary disclosure by state-owned enterprises listed on the stock exchange of Hong Kong. Journal of International Financial Management \& Accounting, 13(2), 125-152.

Firth, M. (1979).The impact of size, stock market listing, and auditors on voluntary disclosure in corporate annual reports.Accounting and Business Research, 9(36), 273280.

Glaum, M., \& Street, D. L. (2003). Compliance with the disclosure requirements of Germany's new market: IAS versus US GAAP. Journal of International Financial Management \& Accounting, 14(1), 64-100.

Guidry, R. P., \& Patten, D. M. (2012, June). Voluntary disclosure theory and financial control variables: An assessment of recent environmental disclosure research. In Accounting Forum (Vol. 36, No. 2, pp. 8190).Elsevier.

Haniffa, R. M., \& Cooke, T. E. (2002).Culture, corporate governance and disclosure in Malaysian corporations. Abacus, 38(3), 317-349.

Healy, P. M., \& Palepu, K. G. (2001). Information asymmetry, corporate 
disclosure, and the capital markets: A review of the empirical disclosure literature. Journal of accounting and economics, 31(1), 405-440.

Heitzman, S., Wasley, C., \& Zimmerman, J. (2010). The joint effects of materiality thresholds and voluntary disclosure incentives on firms' disclosure decisions.Journal of accounting and economics, 49(1), 109-132.

Hossain, M., \& Hammami, H. (2009). Voluntary disclosure in the annual reports of an emerging country: The case of Qatar. Advances in Accounting, incorporating Advances in International Accounting(25), 255-265.

Hossain, M., Perera, M. H. B., \& Rahman, A. R. (1995).Voluntary disclosure in the annual reports of New Zealand companies. Journal of International Financial Management \& Accounting, 6(1), 69-87.

Inchausti, A. G. (1997). The influence of company characteristics and accounting regulation on information disclosed by Spanish firms. European Accounting Review, 6(1), 45-68.

Jaggi, B., \& Low, P. Y. (2000).Impact of culture, market forces, and legal system on financial disclosures. The International Journal of Accounting, 35(4), 495-519.

Jensen, M. C. (1986). Agency costs of free cash flow, corporate finance, and takeovers. The American economic review, 76(2), 323-329.

Jensen, M. C., \& Meckling, W. H. (1976). Theory of the firm: Managerial behavior, agency costs and ownership structure. Journal of financial economics, 3(4), 305-360.

La Porta, R., Lopez-de-Silanes, F., Shleifer, A., \& Vishny, R. (2000). Investor protection and corporate
governance.Journal of financial economics, 58(1), 3-27. 